\title{
Variation in black and white band disease progression in corals of the Gulf of Mannar and Palk Bay, Southeastern India
}

\author{
T. Thinesh ${ }^{1,2}$, G. Mathews ${ }^{1}$, K. Diraviya Raj ${ }^{1}$, J. K. Patterson Edward ${ }^{1}$ \\ ${ }^{1}$ Suganthi Devadason Marine Research Institute, 44 Beach Road, Tuticorin 628 001, Tamil Nadu, India \\ ${ }^{2}$ Present address: Centre for Ecological Sciences, Indian Institute of Science, Bangalore 560012, India
}

\begin{abstract}
Information on the progression of coral diseases and transmission to live corals is scarce despite the fact that coral disease poses one of the most lethal threats to the survival of coral reefs. In this study, in situ progression rates of lesions similar to black band disease (BBD) and white band disease (WBD) were measured in different species of corals from the Gulf of Mannar (GoM) and Palk Bay, southeastern India, during the period between January and December of 2009. Maximum progression rates of 3 and $1.6 \mathrm{~cm} \mathrm{mo}^{-1}$ for $\mathrm{BBD}$ and WBD, respectively, were observed during May, when the temperature exceeded $30^{\circ} \mathrm{C}$. The annual progression rate was 10.9 and $4.9 \mathrm{~cm} \mathrm{yr}^{-1}$ for BBD at GoM and Palk Bay, respectively. Significant variation in the progression rate $(p<0.001)$ was observed between months in all the examined species. Significant correlation between temperature and disease progression rates for BBD $\left(R^{2}=0.875, p \leq 0.001\right)$ and WBD $\left(\mathrm{R}^{2}=0.776, \mathrm{p} \leq 0.001\right)$ was recorded. Rates of disease progression were higher in Palk Bay than in GoM. This could be attributed to the higher temperature coupled with higher anthropogenic activities in Palk Bay. Severe mortality was observed due to both BBD and WBD. No sign of recovery was noticed in the disease-affected colonies at either study site. Anthropogenic activities should be checked, and further research on both the transmission and progression rate and role of the diseases in reef dynamics should be carried out to understand the causal factors in reef degradation and generate a plan to manage the reef properly.
\end{abstract}

KEY WORDS: Black band disease - White band disease $\cdot$ Gulf of Mannar - Palk Bay · Disease progression

Resale or republication not permitted without written consent of the publisher

\section{INTRODUCTION}

The ecological and economic importance of coral reefs is well known. Despite the significance of coral reefs, localized anthropogenic impacts, climaterelated changes and coral disease epizootics are threatening their persistence all over the world, including in India (Wilkinson 2008, Thinesh et al. 2011). Among the threats, diseases have been identified as one of the most important, yet least understood, causal factors in reef degradation worldwide (Harvell et al. 2004). Disease in scleractinian corals has been characterized by detectable signs, identifiable causative agents or pathogens, and/or consistent alterations in coral structure and composition (Peters 1997, Parnell \& Richardson 2002). Among these, black band and white band diseases (BBD and WBD, respectively) have been reported to have caused much damage to coral reefs globally.

BBD was the first disease found to be infecting stony corals (Antonius 1973). Since then, BBDaffected coral species and their geographic distributions have increased alarmingly to 42 different species, including the genera Favia, Favities, Diploria, 
Montastrea, Acropora, Agaricia, Montipora and Poirites, in 26 countries (Green \& Bruckner 2000, Rosenberg \& Loya 2004, Sutherland et al. 2004). Progression and mortality rates of $\mathrm{BBD}$ have also increased over the years (Carlton \& Richardson 1995, Montano et al. 2013). On Caribbean reefs, the progression of BBD damage was at a rate of several centimeters of coral tissue per week, progressing across a single colony at a rate as high as $6.2 \mathrm{~mm}$ $\mathrm{d}^{-1}$, with a mean of $3.1 \mathrm{~mm} \mathrm{~d}^{-1}$ (Rützler \& Santavy 1983, Richardson 1997). In Jamaica, BBD infections spread $3 \mathrm{~km}$ over a 19 mo period, infecting $5.2 \%$ of the massive coral population and causing phase shifts in Caribbean coral reef communities (Bruckner 2002).

WBD is another of the most threatening coral diseases known ever since it was first reported by Gladfelter et al. (1977). Incidence of WBD, resultant mortality, affected coral genera and the linear progression rate over live coral colonies are also increasing and spreading to different geographic locations. WBD generally develops at the base of a coral colony or branch and progresses upwardly towards the branch tips in a concentric ring (Gladfelter 1982, Peters et al. 1983). The rate of progression of WBD over a coral colony was observed up to a lethal $10 \mathrm{~cm}$ $\mathrm{d}^{-1}$ in the Bahamas (USA). Numbers of affected species have increased to 37 species in 18 genera, and the geographic distribution now covers 27 countries (Davis et al. 1986, Antonius 1995, Riegl 2002). Extensive mortality, approximately $40 \%$, in Acroporidae has been reported in the Florida Keys, USA (Antonius 1982). In the Caribbean, Acroporidae have also been particularly devastated, suffering an $80 \%$ regional decline in coral coverage during the last 3 decades (Gardner et al. 2003).

Research results indicate that climate warming (Harvell et al. 2002), water pollution (Szmant 2002) and over-fishing (Jackson et al. 2001) are connected with an increasing incidence of coral diseases (Bruno et al. 2007). However, in many instances, some corals withstand diseases better than others despite being in the same environment (Thinesh et al. 2011). Reefs in the Gulf of Mannar (GoM) and Palk Bay have been seriously degraded due to coral mining (Mahadevan \& Nayar 1972). Currently, the reefs in these areas are recovering through successful coral reproduction and recruitment and, more importantly, because coral mining ceased after the 2004 Indian Ocean tsunami, which increased environmental awareness and led to the introduction of stringent regulations (Patterson Edward et al. 2008, Raj \& Patterson Edward 2010). However, natural factors, such as algal growth, elevated sea-surface temperature and coral diseases, are hampering the recovery of corals. Coral diseases have already been reported as a serious threat to corals in the GoM and Palk Bay (Thinesh et al. 2011, 2013). Yet, no study yet has sought to explain the mystery of how disease progression rates vary between coral species and between sites. Hence, the objective of our study was to investigate the natural progression of BBD and WBD over different live coral species and at different sites.

\section{MATERIALS AND METHODS}

\section{Study sites}

Progression rates of BBD and WBD were studied in 2 different locations, Mandapam Jetty $\left(9^{\circ} 17.379^{\prime} \mathrm{N}\right.$, $\left.79^{\circ} 09.904^{\prime} \mathrm{E}\right)$ of Palk Bay and Shingle Island $\left(9^{\circ} 14.648^{\prime} \mathrm{N}, 79^{\circ} 14.220^{\prime} \mathrm{E}\right)$ of Gulf of Mannar. The geographic distance between both sites is $\leq 4 \mathrm{~km}$. Hence, both the sites have several similarities in terms of species composition, temperature and oceanographic pattern. But exposure to anthropogenic activities differs from one site to the other, as Shingle Island is located in a marine protected area (MPA) called Gulf of Mannar Marine National Park, whereas Mandapam Jetty is under no protection. Palk Bay reefs are under pressure due to its proximal nature $(1 \mathrm{~km})$ to shore, e.g. due to land-based pollution and fishing. Data were collected from each of the sites at a $2 \mathrm{~m}$ depth between January and December 2009. $\mathrm{BBD}$ progression rate was measured in Acropora cytherea and Platygyra lamellina at Mandapam Jetty and in A. cytherea at Shingle Island. WBD progression rate was measured in $A$. cytherea and Montipora digitata at Shingle Island and in A. cytherea at Mandapam Jetty. From both study sites, 5 colonies of each species were selected for both $\mathrm{BBD}$ and WBD tests and 1 branch was tagged. In situ morphological identification of the disease was done using the coral disease handbook by Raymundo \& Harvell (2008). Study sites are shown in Fig. 1.

\section{Measurement of disease progression rate}

The rate of disease progression over a coral colony was measured using the tagging method (English et al. 1997), which helps to monitor disease characteristics at the colony level over time. The branching $(M$. digitata) and table-type coral (A. cytherea), colonies were marked by tying a rope at the recently exposed 


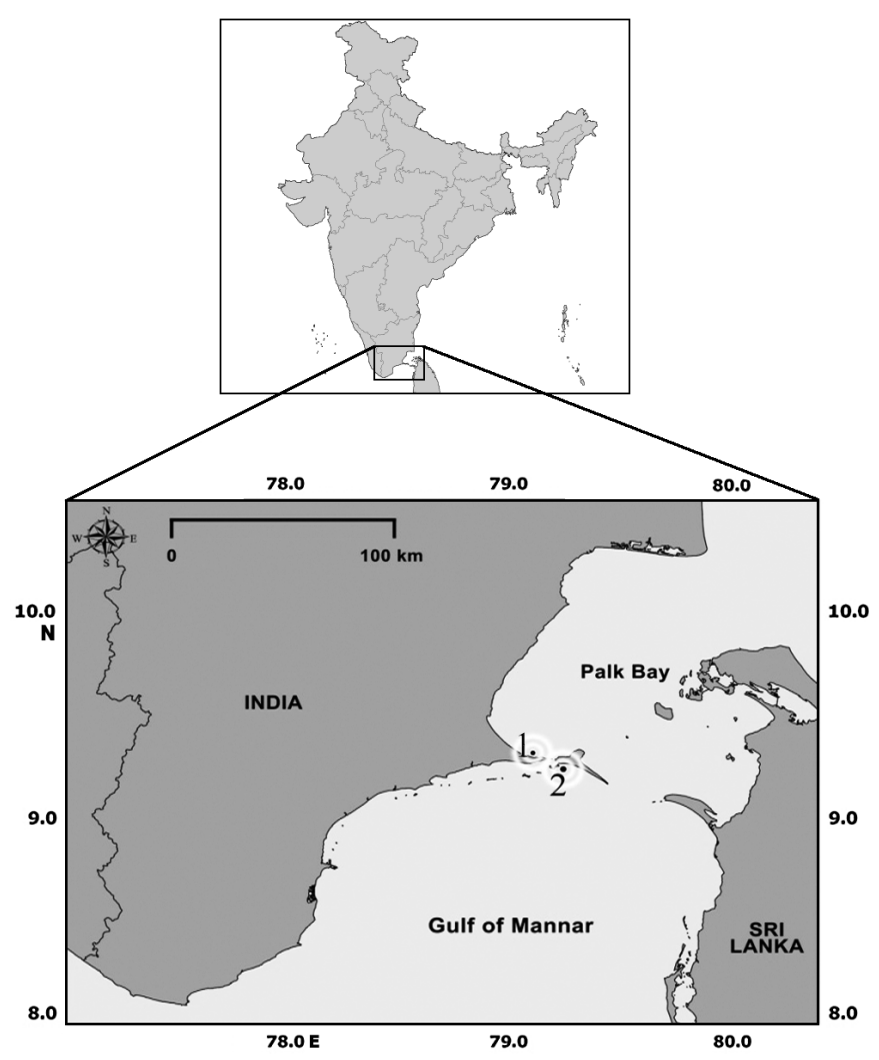

Fig. 1. Palk Bay and Gulf of Mannar study sites (circles labeled 1 and 2, respectively)

skeleton adjacent to live tissue. Distance from the initial marked area to the new lesion front was measured using Vernier caliper. In each subsequent survey new rope was tied at the immediate edge of the advancing front to measure monthly disease progression.

In massive encrusting type ( $P$. lamellina), a nail was hammered into the colony at the immediate edge of the advancing front when the colony was initially tagged. Distance from the nail to the new disease front was measured during subsequent visits with a flexible measuring tape. One-way ANOVA was performed to test for differences in the linear progression rates of $\mathrm{BBD}$ and $\mathrm{WBD}$ between species and between months using statistical software (Graph Pad Prism).

\section{Monitoring of the environmental parameters and statistical analysis}

The physical and chemical parameters, such as temperature (thermometer), salinity (refractometer) and nutrient parameters (phosphates and nitrates)
(Grasshoff et al. 1999), were analyzed during the study period (every month) at sites where disease was prevalent. Correlation analysis was performed to examine the relationship between the disease progression rate and 4 environment variables using statistical software (Graph Pad Prism).

\section{RESULTS}

\section{Progression rate of BBD}

The rate of linear progression of BBD in Platygyra lamellina at Mandapam Jetty in Palk Bay significantly ( $p<0.001$ ) varied between months. The annual progression rate was observed to be $10.4 \mathrm{~cm}$ $\mathrm{yr}^{-1}$ during the study period. The highest mean $( \pm \mathrm{SD})$ progression rate was observed during May, at $2.9 \pm 0.1 \mathrm{~cm} \mathrm{mo}^{-1}$, and the lowest, at 0 between November and February. The maximum progression observed in a single colony was $3 \mathrm{~cm} \mathrm{mo}^{-1}$ during May. No significant differences in BBD progression rates were found between $P$. lamellina and Acropora cytheria in Palk Bay $(\mathrm{p}<0.3262)$. The rate of linear progression of $\mathrm{BBD}$ in $A$. cytherea at Mandapam Jetty significantly $(\mathrm{p}<0.001)$ varied between months. The annual progression rate was observed to be $10.9 \mathrm{~cm} \mathrm{yr}^{-1}$. The highest mean progression rate was observed during May, at $2.9 \pm 0.1 \mathrm{~cm} \mathrm{mo}^{-1}$, and the lowest, at 0 from November to February. The maximum progression value observed in a single colony was $3 \mathrm{~cm} \mathrm{mo}^{-1}$ during May. In situ progression rates of $\mathrm{BBD}$ and $\mathrm{WBD}$ over live coral colonies (detailed experimental underwater photographs) are shown in Fig. 2.

The rate of $\mathrm{BBD}$ progression was relatively slow in the GoM compared to that in Palk Bay. The rate of linear progression of BBD in A. cytherea at Shingle Island (GoM) also varied between months. The annual progression rate was observed to be $4.9 \mathrm{~cm}$ $\mathrm{yr}^{-1}$. The highest mean progression rate was observed during May, at $1.3 \pm 0.1 \mathrm{~cm} \mathrm{mo}^{-1}$, and the lowest, at 0 from October to January. The maximum progression observed in a single colony was $1.4 \mathrm{~cm} \mathrm{mo}^{-1}$ during May.

\section{Progression rate of $\mathrm{WBD}$}

The rate of linear progression of WBD in $A$. cytherea at Mandapam Jetty in Palk Bay also varied significantly between months. The annual progression rate of WBD was observed to be $4.0 \mathrm{~cm} \mathrm{yr}^{-1}$. The 

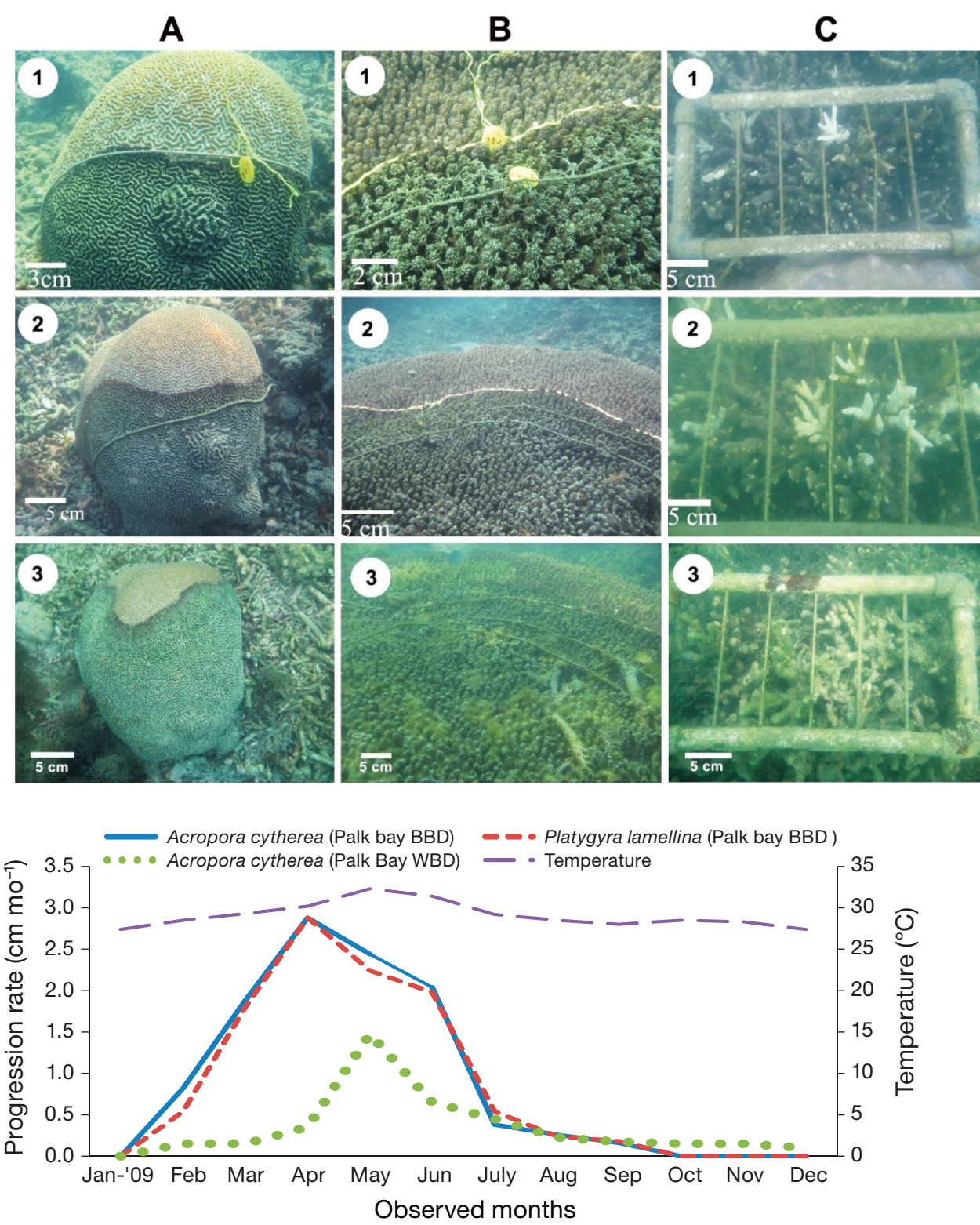

Fig. 3. Changes in disease progression rates of black band disease (BBD) in Acropora cytherea and Platygyra lamellina and white band disease (WBD) in A. cytherea from Palk Bay ( $x$-axis, observed months; $y$-axis, progression rate, and temperature at $2 \mathrm{~m}$ depth)

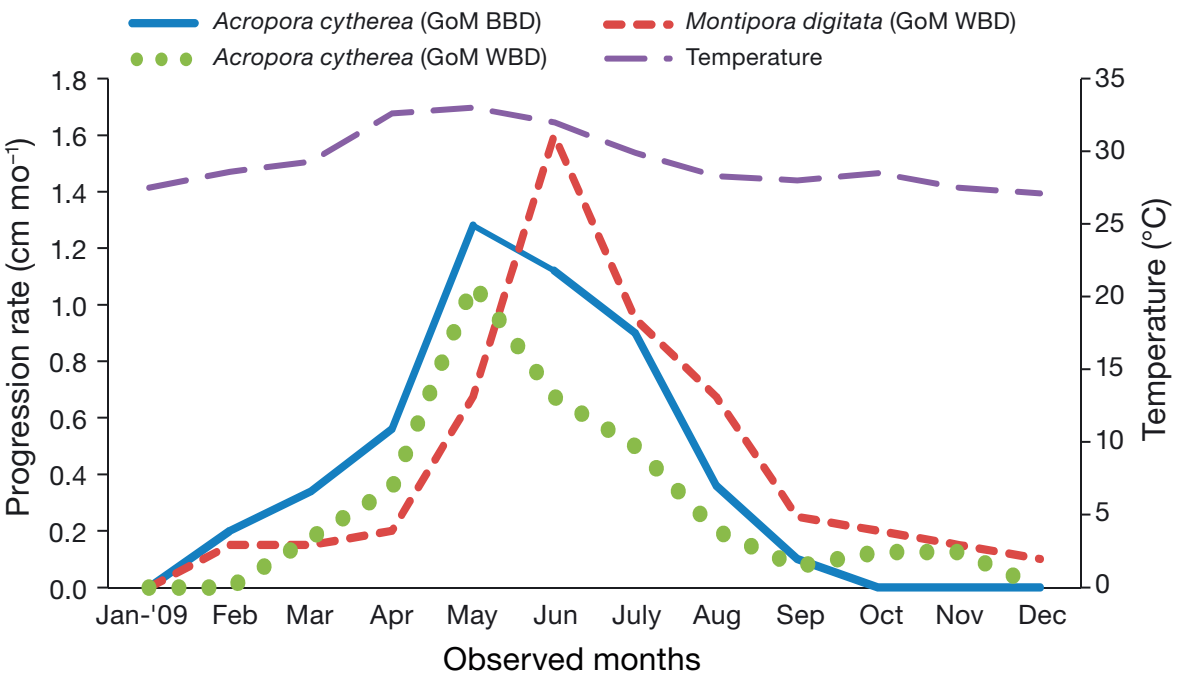

Fig. 4. Changes in disease progression rates of white band disease (WBD) in Acropora cytherea and Montipora digitata and black band disease (BBD) in A. cytherea from the Gulf of Mannar (GoM) ( $x$-axis, observed months; $y$-axis, progression rate, and temperature at $2 \mathrm{~m}$ depth) 
highest mean progression rate $\left(1.5 \pm 0.1 \mathrm{~cm} \mathrm{mo}^{-1}\right)$ was recorded during May, and the lowest mean progression rate was observed at 0 during January. The highest progression value $\left(1.6 \mathrm{~cm} \mathrm{month}^{-1}\right)$ was recorded during May. All the examined diseaseaffected coral colonies died, and no recovery was recorded during the study period.

The rate of linear progression of WBD also varied each month in all the examined species. In Montipora digitata at Shingle Island (GoM) the annual progression rate of WBD was observed to be $5.1 \mathrm{~cm} \mathrm{yr}^{-1}$. The highest mean progression rate was $1.6 \pm 0.1 \mathrm{~cm}$ $\mathrm{mo}^{-1}$ during May, and lowest mean progression rate was observed to be 0 during January. The maximum progression observed in a single colony was $1.7 \mathrm{~cm}$ $\mathrm{mo}^{-1}$ during May. In A. cytherea, the annual progression rate of WBD at Shingle Island (GoM) was observed to be $3.3 \mathrm{~cm} \mathrm{yr}^{-1}$. The highest mean progression rate was observed during May, at $1.1 \pm 0.1 \mathrm{~cm}$ $\mathrm{mo}^{-1}$, and the lowest, at 0 from December to February. The maximum progression rate observed in a single colony was $1.3 \mathrm{~cm} \mathrm{mo}^{-1}$ during May. Details of disease progression over different species at different sites are given in Figs. 3 \& 4 .

\section{Physio-chemical parameters}

A linear relationship between temperature and the disease progression rate over a live coral colony was observed. In Palk Bay, BBD disease progression in A. cytherea and $P$. lamellina correlated with the seasurface temperature (Fig. $5 ; R^{2}=0.776, p \leq 0.002$ and $\mathrm{R}^{2}=0.780, \mathrm{p} \leq 0.002$, respectively).WBD in A. cytheria also correlated with sea-surface temperature $\left(R^{2}=0.594, p \leq 0.002\right)$. No significant correlation was observed for other parameters. In the GoM, BBD progression in A. cytheria and WBD progression in $M$. digitata and $A$. cytheria were correlated with the seasurface temperature (Fig. $6 ; \mathrm{R}^{2}=0.846, \mathrm{p} \leq 0.001$; $\mathrm{R}^{2}=0.4150, \mathrm{p} \leq 0.024 ;$ and $\mathrm{R}^{2}=0.875, \mathrm{p} \leq 0.001$ ， respectively). Observed physio-chemical parameters and their correlation results with disease progression values are given in Tables $1 \& 2$. Correlation between temperature and different diseases at different sites are given in Figs. 5 \& 6 .

One-way ANOVA showed a significant deviation in the monthly progression rate of BBD in A. cytherea and P. lamellina in Palk Bay and of A. cytherea in the GoM $(\mathrm{p}<0.05)$. The progression rates of WBD showed significant deviations between months in $M$. digitata and A. cytheria in the GoM, and A. cytherea in Palk Bay $(\mathrm{p}<0.05)$.

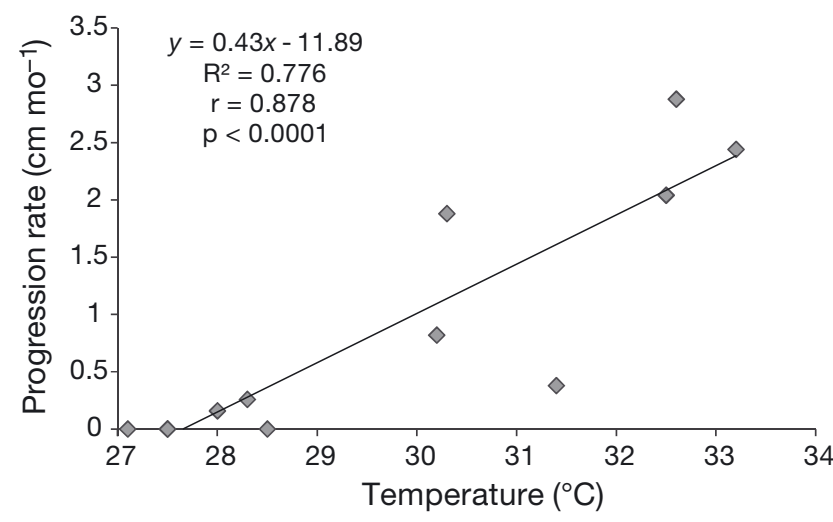

Fig. 5. Linear correlation between temperature at $2 \mathrm{~m}$ depth and monthly black band disease progression rate in Palk Bay for Acropora cytherea

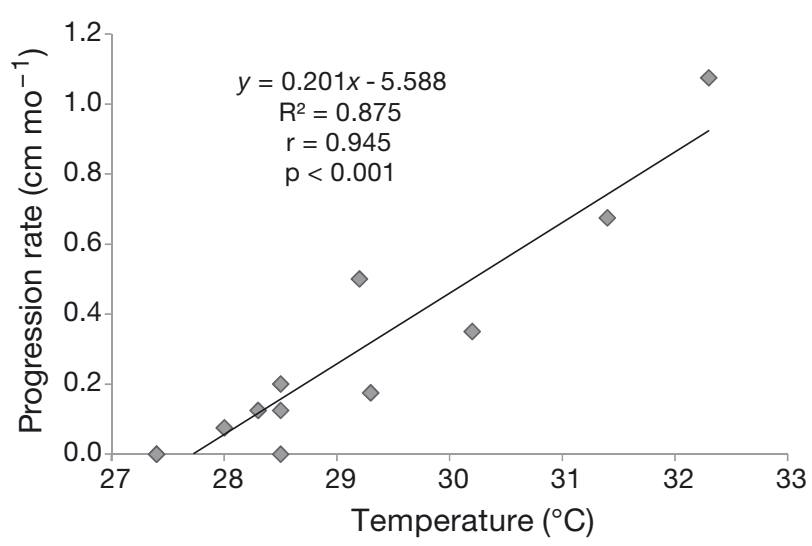

Fig. 6. Linear correlation relationship between temperature at $2 \mathrm{~m}$ depth and monthly white band disease progression rate in the Gulf of Mannar for Acropora cytherea

Table 1. Mean $( \pm \mathrm{SD})$ values of observed physio-chemical parameters from $2 \mathrm{~m}$ depth at both study sites

\begin{tabular}{|lcccc|}
\hline Site & $\begin{array}{c}\text { Temperature } \\
\left({ }^{\circ} \mathrm{C}\right)\end{array}$ & $\begin{array}{c}\text { Salinity } \\
(\mathrm{ppt})\end{array}$ & $\begin{array}{c}\text { Phosphate } \\
\left(\mu \mathrm{g} \mathrm{l}^{-1}\right)\end{array}$ & $\begin{array}{c}\text { Nitrate } \\
\left(\mu \mathrm{g} \mathrm{l^{-1 }}\right)\end{array}$ \\
\hline $\begin{array}{l}\text { Palk Bay } \\
\begin{array}{l}\text { Gulf of } \\
\text { Mannar }\end{array}\end{array}$ & $29.4 \pm 2.1$ & $34.5 \pm 0.8$ & $0.61 \pm 0.23$ & $0.37 \pm 0.11$ \\
\hline
\end{tabular}

\section{DISCUSSION}

BBD and WBD undoubtedly cause mortality in various geographic locations around the world; mortality due to BBD has been reported from 25 countries (Sutherland et al. 2004), while mortality due to WBD has been reported from 27 countries (Gladfelter et al. 1977). According to our observations in the present study, the GoM and Palk Bay, India, can be added to 
Table 2. Physio-chemical parameters and correlation results with disease progression values. BBD: black band disease; WBD: white band disease; GoM: Gulf of Mannar

\begin{tabular}{|lcccccc|}
\hline \multirow{2}{*}{ Observed species } & \multirow{2}{*}{ Site } & Disease & \multicolumn{2}{c}{ Phosphate } & \multicolumn{2}{c}{ Nitrate } \\
& & & $\mathrm{R}^{2}$ & $\mathrm{p}$ & $\mathrm{R}^{2}$ & \multicolumn{2}{c}{$\mathrm{p}$} \\
\hline Acropora cytherea & Palk Bay & BBD & 0.380 & 0.033 & 0.001 & 0.93 \\
Platygyra lamellina & Palk Bay & BBD & 0.368 & 0.037 & 0.000 & 0.99 \\
Acropora cytherea & Palk Bay & WBD & 0.247 & 0.100 & 0.093 & 0.34 \\
Montipora digitata & GoM & WBD & 0.4506 & 0.0168 & 0.1433 & 0.2249 \\
Acropora cytherea & GoM & WBD & 0.5176 & 0.0084 & 0.2005 & 0.1443 \\
Acropora cytherea & GoM & BBD & 0.6419 & 0.0017 & 0.3214 & 0.0546 \\
\hline
\end{tabular}

that list, as all infected coral species from both sites were most often found dead. Disease-affected coral colonies were immediately covered by secondary algae, and, consequently, recovery of infected coral colonies was not expected.

Both BBD and WBD, which migrate over a coral colony, eventually cause mortality. A fast rate of BBD progression has been reported in many locations. For instance, on Caribbean reefs, an average progression rate of $12.5 \mathrm{~mm} \mathrm{~d}^{-1}$ was recorded on an Acropora millipora colony, with a total linear distance of $5 \mathrm{~cm}$ over a $4 \mathrm{~d}$ period (Dinsdale 1994). In the same region, progression on Montastrea annularis has been recorded at a rate of $6.2 \mathrm{~mm} \mathrm{~d}^{-1}$, with a deadly maximum of $2 \mathrm{~cm} \mathrm{~d}^{-1}$ (Kuta \& Richardson 1996). In the present study, the progression rate of BBD over coral colonies was also severe, with a maximum linear progression of $3 \mathrm{~cm} \mathrm{mo}^{-1}$ and a mean progression of $2.9 \pm 0.1 \mathrm{~cm}$ $\mathrm{mo}^{-1}$ during May in Palk Bay for A. cythera and Platygyra lamellina. We found that WBD progressed over live coral colonies at the rate of $1.6 \pm 0.1 \mathrm{~cm}$ $\mathrm{mo}^{-1}$, which is consistent with other results; however, the rate of progression is not consistent with reports of WBD progression in the Florida Keys, where $4 \mathrm{~cm}$ $\mathrm{d}^{-1}$ has been recorded in A. cytherea (Williams \& Miller 2005) and, in the Caribbean, where $5 \mathrm{~mm} \mathrm{~d}^{-1}$ has been recorded in A. palmate (Gladfelter 1991).

The rate in which disease spreads varies between species (Bruno et al. 2007). In Puerto Rico, the linear movement of BBD ranged from 0.5 to $1 \mathrm{~mm} \mathrm{~d}^{-1}$, with variations among species, reefs and depths. The slowest increase was among Siderastrea siderea, and the fastest, among $M$. annularis (Bruckner 1999). We also found variation in the progression of WBD between different species in the GoM, with $1.7 \mathrm{~cm}$ $\mathrm{mo}^{-1}$ and a mean value of $1.6 \pm 0.1 \mathrm{~cm} \mathrm{mo}^{-1}$ for Montipora digitata, and with $1.3 \mathrm{~cm} \mathrm{mo}^{-1}$ and a mean value of $0.7 \pm 0.1 \mathrm{~cm} \mathrm{mo}^{-1}$ for $A$. cytherea, which shows that resistance varies between species. This variation in resistance from one species to another can be attributed to the cellular and humoral factors that make up the immune system (Mullen et al. 2004). In the case of BBD, no variation in the progression rate was observed between species within a specific site, which may be because both have the same resistance capacity or no resistance at all at that particular site. However, considering one specific species, differences were found in progression rates between the GoM and Palk Bay; these may be related to anthropogenic stress, which would indicate that ecological factors are involved in the variation in resistance (Palmer et al. 2011). Though the rate of BBD progression is comparatively slow in both Palk Bay and the GoM, even this rate is sufficient to cause severe mortality in both Palk Bay and the GoM, similar to its effects in the Caribbean (Bruckner et al. 1997).

Several studies have highlighted the role of temperature on the prevalence of coral diseases (Antonius 1982, Rützler \& Santavy 1983, Edmunds 1991, Kuta \& Richardson 1996). The highest prevalence of BBD on Jamaican coral reefs was recorded during summer months and the lowest prevalence was recorded in the same area during winter months (Bruckner \& Bruckner 1997). On the Great Barrier Reef WBD was also reportedly more active during the summer months (Bruno et al. 2007). Likewise, the highest progression rates for both $\mathrm{BBD}$ and WBD were also recorded here during May, when the seasurface temperature attains its summer maximum.

Observations in Palk Bay and the GoM not only support the studies which reported temperature to be an important factor influencing BBD prevalence but also support the hypothesis that synergistic effects (when temperature and stress are combined) have a greater influence on disease progression (Richardson \& Kuta 2003, Willis et al. 2004). In the present study, both BBD and WBD had higher linear progression rates in Palk Bay than in the GoM, while the trend is similar in both areas. The higher progression rate is attributable to the higher anthropogenic activities in Palk Bay (Ramesh et al.1996, Sukumaran et al. 2011), 
which may decrease host resistance. Domestic pollution, fishing harbor activities, trap fishing, anchoring and sea weed culture are very common in Palk Bay due to its proximity to the shore. Furthermore, a huge difference in protection strategies exist as the GoM is a designated MPA and very few protection measures have been established for Palk Bay. Hence, in Palk Bay, due to various natural and anthropogenic disturbances, reef immunity may be compromised by alterations in the basic biological and physiological properties of corals (Rosenberg \& Ben-Haim 2002). Nutrient parameters did not show any significant differences between sites, an observation that contradicts the findings of other studies (Bruno et al. 2003, Sutherland et al. 2004), in which nutrient levels appeared to influence disease prevalence. However, our present observations support the results of Gochfeld et al. (2006), who concluded that nutrient enrichment does not affect disease prevalence.

The findings in this study show that temperature coupled with environmental disturbances influence the disease progression rate more than temperature alone. We also found variability in the disease response between different species in the same study site and between the same species at different sites. This variability in the disease response may be due to many factors. Hence, further work should be carried out to better understand the factors determining resistance and susceptibility in order to generate a strategic plan to save the reefs of India (which provide a source of livelihood for people living along a $8000 \mathrm{~km}$ coastal stretch) from increasing anthropogenic and climatic threats. At the same time, immediate measures should be taken to control the anthropogenic activities in order to save the remaining coral reefs of the GoM and Palk Bay, which were once considered a biologist's paradise.

Acknowledgements. The authors are grateful to the Ministry of Environment and Forests, Government of India, for financial support. We are also grateful to the Principle Chief Conservator of Forests Chief Wildlife Warden, the Tamil Nadu Forest Department and Wildlife Warden and the Gulf of Mannar Marine National Park for research permits, and to the Suganthi Devadason Marine Research Institute for providing research facilities.

\section{LITERATURE CITED}

Antonius A (1973) New observations on coral destruction in reefs. 10th Meeting Assoc Isl Mar Lab Caribb 10:3 (Abstract)

Antonius A (1982) The 'band' diseases in coral reefs. Proc 4th Int Coral Reef Symp, Manila 2:7-14

Antonius A (1995) Pathologic syndromes on reef corals: a review. Publ Serv Geol Lux 29:161-169
Bruckner AW (1999) Black band disease (BBD) of scleractinian corals: occurrence, impacts and mitigation. $\mathrm{PhD}$ dissertation, University of Puerto Rico, San Juan

Bruckner AW (2002) Potential application of the U.S. Endangered Species Act as a conservation strategy. NOAA Tech Memo NMFS-OPR-24, NOAA, Silver Spring, MD

Bruckner AW, Bruckner RJ (1997) The persistence of blackband disease in Jamaica: impact on community structure. Proc 8th Int Coral Reef Symp, Panama City 1: 601-606

Bruckner A, Bruckner R, Williams EJ (1997) Spread of a black-band disease epizootic through the coral reef system in St. Ann's Bay, Jamaica. Bull Mar Sci 61:918-928

Bruno JF, Petes LE, Harvell CD, Hettinger A (2003) Nutrient enrichment can increase the severity of coral diseases. Ecol Lett 6:1056-1061

Bruno JF, Selig ER, Casey KS, Page CA and others (2007) Thermal stress and coral cover as drivers of coral disease outbreaks. PLoS Biol 5:e124

Carlton RG, Richardson LL (1995) Oxygen and sulfide dynamics in a horizontally migrating cyanobacterial mat: black band disease of corals. FEMS Microbiol Ecol 18: 155-162

Davis ME, Gladfelter H, Anderson LM (1986) Geographic range and research plan for monitoring white band disease. Virgin Islands Resource Management Cooperative. Biosphere Res Rep 6:28

Dinsdale E (1994) Coral black band disease: susceptibility, prevalence, community level influences and histopathology. Masters qualifying project, James Cook University, Townsville

Edmunds PJ (1991) Extent and effect of black band disease on Caribbean reefs. Coral Reefs 10:161-165

English S, Wilkinson C, Baker V (1997) Survey manual for marine resources, 2nd edn. Australian Institute of Marine Science, Townsville

> Gardner TA, Cote IM, Gill JA, Grant A, Watkinson AR (2003) Long-term region-wide declines in Caribbean corals. Science 301:958-960

Gladfelter WB (1982) White-band disease in Acropora palmata implications for structure and growth of shallow reefs. Bull Mar Sci 32:639-643

Gladfelter WB (1991) Population structure of Acropora palmata on the windward forereef, Buck Island National Monument: seasonal and catastrophic changes 19881989. In: Gladfelter EH, Bythell JC, Gladfelter WB (eds) Ecological studies of Buck Island Reef National Monument, St. Croix, US Virgin Islands. A quantitative assessment of selected components of the coral reef ecosystem and establishment of long-term monitoring sites. US Department of the Interior, National Park Service, St. Croix, p 1-21

Gladfelter WB, Gladfelter EH, Monahan RK, Ogden JC, Dill RF (1977) Environmental studies of Buck Island Reef National Monument, St. Croix, US Virgin Islands. Spec Rep Nat Park Serv, US Dept Interior, Washington, DC

> Gochfeld DJ, Olson JB, Slattery M (2006) Colony versus population variation in susceptibility and resistance to dark spot syndrome in the Caribbean coral Siderastrea siderea. Dis Aquat Org 69:53-65

Grasshoff K, Kremling K, Ehrhardt M (1999) Methods of seawater analysis, 3rd edn.Verlag Chemie, Weinheim

> Green E, Bruckner AW (2000) The significance of coral disease epizootiology for coral reef conservation. Biol Conserv 96:347-361 
Harvell CD, Mitchell CE, Ward JR, Altizer S, Dobson AP, Ostfeld RS, Samuel MD (2002) Climate warming and disease risk for terrestrial and marine biota. Science 296: 2158-2162

Harvell D, Aronson R, Baron N, Connell J and others (2004) The rising tide of ocean diseases: unsolved problems and research priorities. Front Ecol Environ 2:375-382

> Jackson JBC, Kirby MX, Berger WH, Bjorndal KA and others (2001) Historical overfishing and the recent collapse of coastal eco-systems. Science 293:629-637

Kuta KG, Richardson LL (1996) Abundance and distribution of black band disease of corals in the northern Florida Keys. Coral Reefs 15:219-223

Mahadevan S, Nayar KN (1972) Distribution of coral reefs in the Gulf of Mannar and Palk Bay and their exploitation and utilization. Proc 1st Int Coral Reef Symp, Mandapam Camp, India 1:181-190

Montano S, Giovanni S, Davide S, Paolo G (2013) Prevalence, host range, and spatial distribution of black band disease in the Maldivian Archipelago. Dis Aquat Org 105:65-74

Mullen K, Peters E, Harvell DC (2004) Coral resistance to disease. In: Rosenberg E, Loya Y (eds) Coral health and disease. Springer-Verlag, Berlin, p 377-399

Palmer CV, Traylor-Knowles NG, Willis BL, Bythell JC (2011) Corals use similar immune cells and wound-healing processes as those of higher organisms. PLoS ONE 6(8):e23992

Parnell P, Richardson R (2002) NOAA's coral health and monitoring program, coral disease identification and information. Available at: www.coral.noaa.gov

Patterson Edward JK, Mathews G, Raj KD, Tamelander J (2008) Coral reefs of the Gulf of Mannar, southeastern India - observations on the effect of elevated SST during 2005-2008. Proc 11th Coral Reef Symp, Fort Lauderdale, FL 2:1292-1294

Peters EC (1997) Diseases of coral-reef organisms. In: Birkeland C (ed) Life and death of coral reefs. Chapman \& Hall, New York, NY, p 114-139

Peters EC, Oprandy J, Yevich P (1983) Possible cause of 'white band disease' in Caribbean corals. J Invertebr Pathol 41:394-396

Raj KD, Patterson Edward JK (2010) Observations on the reproduction of Acropora corals along the Tuticorin coast of the Gulf of Mannar, southeastern India. Indian J Mar Sci 39:219-226

Ramesh D, Kannupandi T, Hoon V (1996) Recent changes in the coral reef ecosystem of Palk Bay: a comparative status of previous reports and researches. In: Proceedings of the Regional Workshop on the Conservation and Sus-

Editorial responsibility: Garriet Smith,

Aiken, South Carolina, USA tainable Management of Coral Reefs, No. 22. Centre for Research on Sustainable Agricultural and Rural Development, Chennai, p 123-130

Raymundo LJ, Harvell CD (2008) The objectives and scope of this manual. In: Raymundo LJ, Couch CS, Harvell CD (eds) Coral disease handbook. Currie Communications, Melbourne, p 7-16

Richardson LL (1997) Occurrence of the black band disease cyanobacterium on healthy corals of the Florida Keys. Bull Mar Sci 61:485-490

Richardson LL, Kuta KG (2003) Ecological physiology of the black band disease cyanobacterium Phormidium corallyticum. FEMS Microbiol Ecol 43:287-298

Riegl B (2002) Effects of the 1996 and 1998 positive seasurface temperature anomalies on corals, coral diseases and fish in the Arabian Gulf (Dubai, UAE). Mar Biol 140: $29-40$

Rosenberg E, Ben-Haim Y (2002) Microbial diseases of corals and global warming. Environ Microbiol 4:318-326

Rosenberg E, Loya Y (2004) Coral health and disease. Springer-Verlag, Berlin

Rützler K, Santavy DL (1983) The black band disease of Atlantic reef corals. I. Description of the cyanophyte pathogen. Mar Ecol 4:301-319

Sukumaran S, George RM, Vinod K, Sobhana KS, Naomi TS, Manisseri MK (2011) Temporal patterns in biodiversity and health status of reef corals of Palk Bay. Indian J Fish 58:73-77

Sutherland KP, Porter JW, Torres C (2004) Disease and immunity in Caribbean and Indo-Pacific zooxanthellate corals. Mar Ecol Prog Ser 266:273-302

Szmant AM (2002) Nutrient enrichment on coral reefs: Is it a major cause of coral reef decline? Estuaries 25:743-766

Thinesh T, Mathews G, Patterson Edward JK (2009) Coral disease prevalence in Mandapam group of islands, Gulf of Mannar, southeastern India. Indian J Mar Sci 38: 444-450

Thinesh T, Mathews G, Patterson Edward JK (2011) Coral disease prevalence in the Palk Bay, southeastern Indiawith emphasis to black band. Indian J Geo-Mar Sci 40: 813-820

Wilkinson C (ed) (2008) Status of coral reefs of the world 2008. Australian Institute of Marine Science, Townsville

Williams DE, Miller MW (2005) Coral disease outbreak: pattern, prevalence and transmission in Acropora cervicornis. Mar Ecol Prog Ser 301:119-128

Willis BL, Page CA, Dinsdale EA (2004) Coral disease on the Great Barrier Reef. In: Rosenberg E, Loya Y (eds) Coral health and disease. Springer-Verlag, Berlin, p 69-104

Submitted: October 7, 2014; Accepted: April 9, 2014

Proofs received from author(s): June 20, 2014 